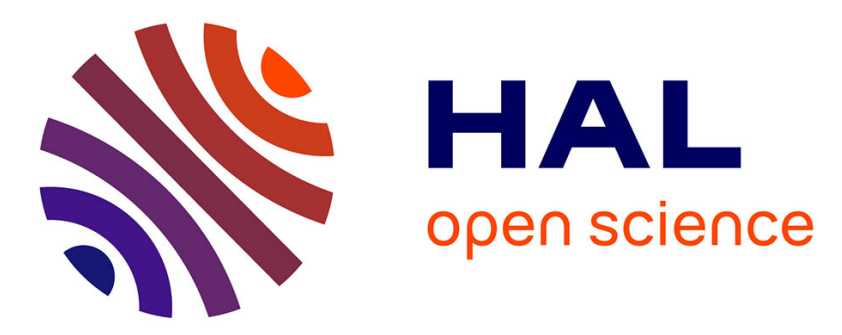

\title{
The Catalytic Effect of Vanadium on the Reactivity of Petroleum Cokes with NO
}

Sylvain Salvador, Jean-Michel Commandre, Brian Stanmore, Roger Gadiou

\section{To cite this version:}

Sylvain Salvador, Jean-Michel Commandre, Brian Stanmore, Roger Gadiou. The Catalytic Effect of Vanadium on the Reactivity of Petroleum Cokes with NO. Energy \& Fuels, 2004, 18 (2), pp.296-301. 10.1021/ef0300489 . hal-02886105

\section{HAL Id: hal-02886105 https://imt-mines-albi.hal.science/hal-02886105}

Submitted on 1 Jul 2020

HAL is a multi-disciplinary open access archive for the deposit and dissemination of scientific research documents, whether they are published or not. The documents may come from teaching and research institutions in France or abroad, or from public or private research centers.
L'archive ouverte pluridisciplinaire HAL, est destinée au dépôt et à la diffusion de documents scientifiques de niveau recherche, publiés ou non, émanant des établissements d'enseignement et de recherche français ou étrangers, des laboratoires publics ou privés. 


\title{
The Catalytic Effect of Vanadium on the Reactivity of Petroleum Cokes with NO
}

\author{
S. Salvador, ${ }^{\dagger, \S}$ J .-M. Commandré, ${ }^{\dagger}$ B. R. Stanmore, ${ }^{\dagger}$ and R. Gadiou*,‡ \\ Ecole des Mines d'Albi-Carmaux, Laboratoire de Génie de Procédés des Solides Divisés, \\ UMR CNRS 2392, Campus J arlard, route de Teillet, 81013 Albi CT cedex 09, France, and \\ Laboratoire de Gestion des Risques et Environnement, 25, rue de Chemnitz, \\ 68200 Mulhouse, France
}

\begin{abstract}
Petroleum cokes are widely used in cement plants for energy generation. Because of their very low volatile content, the physi cochemical processes occurring during their combustion should be mainly controlled by heterogeneous reactions. The reactivities of some petrol eum cokes toward NO between 800 and $1000{ }^{\circ} \mathrm{C}$ have been characterized through experiments in an entrained flow reactor. These carbonaceous materials exhibit very high reactivities toward NO. Their capacity to reduce NO concentration in the surrounding gas is significant, so that this reaction can have a significant impact in terms of $\mathrm{NO}$ emissions resulting from their combustion. The influence of surface area and of the heavy metal content on surface reactivity was tested. As it was the case for carbon-oxygen reaction, the surface measured by mercury porosimetry seems to be a good parameter to calculate surface reaction rate. No correlation was found between cal cium or iron content and NO-carbon reaction rate. As for the reaction of petroleum coke with oxygen, vanadium appears to have a catalytic effect on the reduction reaction of $\mathrm{NO}$ with carbon.
\end{abstract}

\section{Introduction}

Petroleum coke, a residue of the petroleum refining industry, is used today in large quantities as a source of energy. This solid fuel has the advantage of being easy to grind, of containing a high calorific value (between 32.5 and $34.5 \mathrm{MJ} \mathrm{kg}^{-1}$ ), and of being cheap in the market place. For cement plant precalciner applications, it is ground to approximately $50 \%<90 \mu \mathrm{m}$, and used as a coal replacement fuel. It has al so been used in fluidized bed combustors, generally co-fired with coal. ${ }^{1,2}$ The previous years of utilization have identified a number of specificities in their utilization, particularly in terms of process control and of pollutant formation. Very little literature has been devoted to these fuels, making it difficult to interpret the differences observed in their behavior as compared with coal.

Because of the low volatile matter content of this type of fuel, the importance of heterogeneous reactions should be enhanced both for the oxidation of the carbonaceous material or for the formation of pollutants. The wide variation of reactivities of petroleum cokes toward oxygen has al ready been demonstrated in a previous paper; ${ }^{3}$ it has been shown that these variations

* Corresponding author. Tel: (33)3 893276 55. Fax: (33)3 8932 76 61. E-mail: R.Gadiou@uha.fr.

† Ecole des Mines d'Albi-Carmaux.

₹ Laboratoire de Gestion des Risques et Environnement.

§ Tel: (33)5 634931 27. Fax: (33)5 634932 43. E-mail: salvador@ enstimac.fr.

(1) Anthony, E. J . Fluidized bed combustion of alternative solid fuels: status, successes and problems of the technology. Prog. Energy Combust. Sci. 1995, 25, 239-268.

(2) Anthony, E. J .; I ribarne, A. P.; Talbot, R.; J ia, L.; Granatstein, D. L. Fouling in a $160 \mathrm{MWe} F \mathrm{BC}$ boiler firing coal and petroleum coke. Fuel 2001, 80, 1009-1014. can be correlated with the catalytic effects of vanadium. The emissions of nitrogen oxides at the exhaust of a combustor are the result of a balance between the formation of $\mathrm{NO}$ and its reduction by homogeneous and heterogeneous reactions. Therefore, the heterogeneous reduction of $\mathrm{NO}$ on petrol eum coke is expected to influence the nitrogen oxide level in the exhaust, and the determination of its reactivity toward NO is of interest.

The reduction of nitrogen monoxide by different sorts of carbonaceous solids has been the aim of many studies since the 1980's, because this phenomenon is important in fluidized bed combustion. ${ }^{4}$ Despite this large amount of published material, numerous uncertainties still remain. The mechanism of the reaction itself is not fully understood although many attempts have been presented. ${ }^{5,6}$ Because of this lack of established mechanism, most authors have tried to fit their experimental data with global kinetic laws. But, as it has been shown by Aarna and Suuberg in their review, ${ }^{7}$ large variations are observed between published data, whatever the temperature.

(3) Salvador, S.; Commandré, J . M.; Stanmore, B. Reaction rate for the oxidation of highly sulphurised petroleum cokes: the influence of thermogravimetric conditions and some coke properties. Fuel 2003, $82,715-720$

(4) J ohnsson, J . E. Formation and reduction of nitrogen oxides in fluidized bed combustion. Fuel 1994, 73 (9), 1398-1415.

(5) Chan, L. K.; Sarofim, A. F.; Beer, J. M. Kinetics of the NOcarbon reaction at fluidized bed combustion conditions. Combust. Flame 1983, 52, 37-45.

(6) De Soete, G. G. Heterogeneous $\mathrm{N}_{2} \mathrm{O}$ and $\mathrm{NO}$ formation from bound nitrogen atoms during coal char combustion. 23rd Symposium (International) on Combustion; The Combustion Institute: Pittsburgh, 1990; pp 1257-1264.

(7) Aarna, I.; Suuberg, E. M. A review of the kinetics of the nitric oxide-carbon reaction. Fuel 1997, 76 (6), 475-491. 
To explain these differences, the chemical structure and the textural properties of the solid are the most often investigated parameters. Rodriguez-Mirasol et al. ${ }^{8}$ studied the influence of the rank of the parent coal on the reactivity of the char toward NO in a small scale fixed bed. He observed that lignite chars are more reactive than chars obtained from high rank coals; the graphitic structure of the char is therefore an important parameter in the determination of the reactivity. A study by Zevenhoven and $\mathrm{Hupa}^{9}$ on a larger number of chars led to the same conclusion. Neverthel ess, these results may be mainly a consequence of the differences in texture and chemical composition of the samples. A more precise study of this point has been made by Gulyurtlu et al. who used char prepared at differents temperatures from the same raw coal. ${ }^{10}$ The authors observed that the higher the preparation temperature, the more reactive the sample is. This result could be explained by an increase of surface area and also by the graphitization of the carbon structure.

To take into account the influence of the texture of the samples, most authors calculated the specific reaction rate by dividing the global rate of reaction by a surface area. This last parameter is either the $\mathrm{CO}_{2}$ adsorption surface or the $\mathrm{N}_{2}$ adsorption surface computed by the BET equation. Shimizu used the former surface and found a constant value of the specific reaction rate for nine samples which had surfaces ranging between 250 and $900 \mathrm{~m}^{2} / \mathrm{g} .{ }^{11}$ Illian-Gomez et al. ${ }^{12}$ observed also a linear correlation between the reaction rate of carbon samples at $873 \mathrm{~K}$ and the $\mathrm{BET}$ surface area. Nevertheless, other studies showed that the specific reaction rate presents large variations as a function of the chemical composition of the carbonaceous samples.

With an experimental setup similar to RodriguezMirasol, Chan et al. ${ }^{5}$ examined the influence of mineral matter, and observed that the demineralization of a lignite char leads to a decrease in its reactivity with NO by an order of magnitude. As for the carbon-oxygen reaction, many elements can have a catalytic effect on the NO-char and the $\mathrm{N}_{2} \mathrm{O}-$ char reactions. Chan et al. ${ }^{5}$ and Zevenhoven and $\mathrm{Hupa}^{9}$ observed that the calcium content of the most reactive char, i.e., the lignite char, was high. Illan-Gomez et al. studied the influence of mineral matter on the rate of NO reduction over chars. They observed that whatever the temperature, the addition of a metal such as $\mathrm{Fe}, \mathrm{Cu}$, or $\mathrm{Ni}$ decreases the activation energy of the reaction.13,14 The catalytic activity of potassium and calcium was also observed. ${ }^{15,16}$

(8) Rodriguez-Mirasol, J .; Ooms, A. C.; Pels, J. R.; Kapteijn, F.; Moulijn, J. A. NO and $\mathrm{N}_{2} \mathrm{O}$ decomposition over coal char at fluidizedbed combustion conditions. Combust. Flame 1994, 99, 499-505.

(9) Zevenhoven, R.; Hupa, M. The reactivity of chars from coal, peat, and wood toward NO, with and without CO. Fue 1998, 77 (11), 11691176.

(10) Gulyurtlu, I.; Esparteiro, $\mathrm{H}$.; Cabrital, I. $\mathrm{N}_{2} \mathrm{O}$ formation during fludized bed combustion of chars. Fuel 1994, 73 (7), 1098-1102.

(11) Shimizu, T.; Sazawa, Y.; Adschiri, T.; F urusawa, T. Conversion of char-bound nitrogen to nitric oxide during combustion. Fuel 1992, 71, 361.

(12) Illan-Gomez, M. J .; Linares-Solano, A.; Salinas-Martinez de Lecea, C.; Calo, J. M. NO reduction by activated carbons. 1. The role of carbon porosity and surface area. Energy Fuels 1993, 7, 146154

(13) Illan-Gomez, M.J .; Linares-Solano, A.; Radovic, L. R.; SalinasMartinez de Lecea, C. NO Reduction by Activated Carbons. 5. Catalytic Effect of Iron. Energy Fuels 1995, 9, 540-548.
Some authors tried to remove the mineral matter of chars in order to quantify the decrease in the reaction rate. ${ }^{17-19}$ The main problem is that the demineralization is never complete, so that a catalytic activity remains; another problem is that the preparation of the sample changes the textural properties of the carbonaceous solid. Despite these difficulties, a decrease of the rate of the reduction of $\mathrm{NO}$ on the char surface was observed in all cases.

In this work, we have characterized the kinetics of the reaction of NO reduction on the char surface of a number of petroleum cokes between 800 and $1000{ }^{\circ} \mathrm{C}$. This temperature range is representative either for $\mathrm{FBC}$ combustion of petroleum coke or for the precalciner of cement plants. As we will demonstrate, this reaction has a significant impact on the global emissions of $\mathrm{NO}$ resulting from the combustion of the petcokes.

\section{Experimental Section}

2.1. Experimental Setup. To characterize the reaction kinetics in conditions close to those of a fluidized bed or of an entrained flow such as a cement plant precalciner, a set of experiments was carried out in a laboratory scale entrained flow reactor (EFR). Although many different experimental devices may be used to obtain heterogeneous reactions kinetics such as a thermogravimetric apparatus or fixed beds, $, 8,20$ the EFR has been widely used because it allows the dispersion of particles in a gas flow. Therefore the diffusion limitations observed in fixed beds can be avoided. Another advantage is that high temperatures may be reached. ${ }^{21,22}$

The reactor design has al ready been detailed elsewhere. ${ }^{3,23}$ The apparatus shown in Figure 1 consists of an $80 \mathrm{~mm}$ i.d. and $1 \mathrm{~m}$ long isothermal fused silica reactor fed with an electrically preheated gas flow. A stream of powdered fuel particles was injected through a water-cooled feeding probe. Care was taken to obtain a good dispersion of the particles on a cross section of the reactor by placing a dispersion dome 1 $\mathrm{mm}$ downstream from the tip of the feeding probe.

The gas was sampled after a controlled residence time through a water-cool ed nitrogen-quenched probe. It was then analyzed; $\mathrm{NO}, \mathrm{CO}$, and $\mathrm{CO}_{2}$ were quantified by on-line NDIR

(14) Illan-Gomez, M. J .; Linares-Solano, A.; Salinas-Martinez de Lecea, C. NO Reduction by Activated Carbons. 6. Catalysis by transition metals. Energy Fuels 1995, 9, 976-983.

(15) Illan-Gomez, M. J .; Linares-Solano, A.; Radovic, L. R.; SalinasMartinez de Lecea, C. NO Reduction by Activated Carbons. 2. Catalytic Effect of Potassium. Energy Fuels 1995, 9, 97-103.

(16) Illan-Gomez, M. J .; Linares-Solano, A.; Radovic, L. R.; SalinasMartinez de Lecea, C. NO Reduction by Activated Carbons. 3. Catalysis by Calcium. Energy Fuels 1995, 9, 112-118.

(17) Guo, F.: Hecker, W. C. Effects of $\mathrm{CaO}$ and burnout on the kinetics of reduction by Beulah zap char. 26th Symposium (International) on Combustion; The Combustion Institute: Pittsburgh, 1996; pp 2251-2257.

(18) Aarna, I.; Suuberg, E. M. The role of carbon monoxide in the NO-carbon reaction. Energy Fuels 1999, 13, 1145-1153.

(19) Peter, M. Reactivite des oxydes d'azote formes lors de la combustion de charbon en lit fluidise circulant. Ph.D. Thesis, University of Mulhouse, 2000

(20) Suuberg, E. M.; Teng, H.; Calo, J. M. Studies on the kinetics and mechanism of the reaction of NO with carbon. 23rd Symposium (International) on Combustion; The Combustion Institute: Pittsburgh 1990; pp 1199-1205.

(21) Levy, J . M.; Chan, L. K.; Sarofim, A. F.; Beer, J . M. NO-char reactions at pulverized coal flame temperatures. 18th Symposium (International) on Combustion; The Combustion Institute: Pittsburgh 1980; pp 111-120.

(22) Song, Y. H.; Beer, J . M.; Sarofim, A. F. Reduction of Nitric Oxide by Coal Char at Temperatures of 1250-1750 K. Combust. Sci. Technol. 1981, 25, 237-240.

(23) Van de Steene, L.; Salvador, S.; Charnay, G. Controlling powdered fuel combustion at low temperature in a new entrained flow reactor. Combust. Sci. Technol. 2000, 159, 255-279. 
Table 1. Ultimate and Proximate Analysis and Lower Calorific Value of the Samples ${ }^{a}$

\begin{tabular}{|c|c|c|c|c|c|c|c|c|c|c|c|}
\hline \multirow[b]{2}{*}{ sample } & \multicolumn{5}{|c|}{ ultimate analysis (\% raw) } & \multicolumn{2}{|c|}{ proximate analysis (\% raw) } & \multirow[b]{2}{*}{$\mathrm{LCV}(\mathrm{kJ} / \mathrm{g})$} & \multicolumn{3}{|c|}{ surface analysis } \\
\hline & $\mathrm{C}$ & $\mathrm{H}$ & $\mathrm{O}$ & $\mathrm{S}$ & $\mathrm{N}$ & VM & ash & & $\operatorname{BET}\left(m^{2} / g\right)$ & $\mathrm{Hg}_{20}\left(\mathrm{~m}^{2} / \mathrm{g}\right)$ & $\epsilon$ \\
\hline petcoke Lily & 87.8 & 3.51 & 1.1 & 7.47 & 1.61 & 10.5 & 0.33 & 34.45 & 4.5 & 1.77 & 0.57 \\
\hline petcoke Havre CDP & 87.9 & 3.51 & 1.1 & 7.08 & 1.51 & 10.1 & 0.38 & 34.35 & 10.0 & 2.20 & 0.57 \\
\hline petcoke Asland & 89.4 & 3.60 & & 4.02 & 1.88 & 10.1 & 0.47 & 34.50 & 5.3 & 1.82 & 0.59 \\
\hline petcoke Villauengas & 88.4 & 3.70 & & 6.16 & 1.56 & 11.0 & 0.12 & 34.35 & 6.2 & 2.00 & 0.65 \\
\hline petcoke St Constant & 88.5 & 1.94 & & 6.00 & 1.63 & 5.2 & 0.50 & 32.50 & 6.3 & 1.33 & 0.54 \\
\hline petcoke Niebla & 85.8 & 3.50 & & 5.85 & 1.70 & 11.1 & 3.35 & 33.40 & 4.8 & 1.80 & 0.66 \\
\hline coal I van & 67.0 & 4.54 & 11.3 & 0.24 & 1.85 & 30.7 & 13.23 & 25.95 & 64.0 & 8.30 & 0.73 \\
\hline activated carbon & 85.9 & 0.60 & & 0.50 & 0.11 & & 2.70 & & 890.0 & 12.89 & 0.78 \\
\hline
\end{tabular}

a The BET, the $\mathrm{Hg}_{20}$ surface area, and the porosity $\epsilon$ are those of the chars.

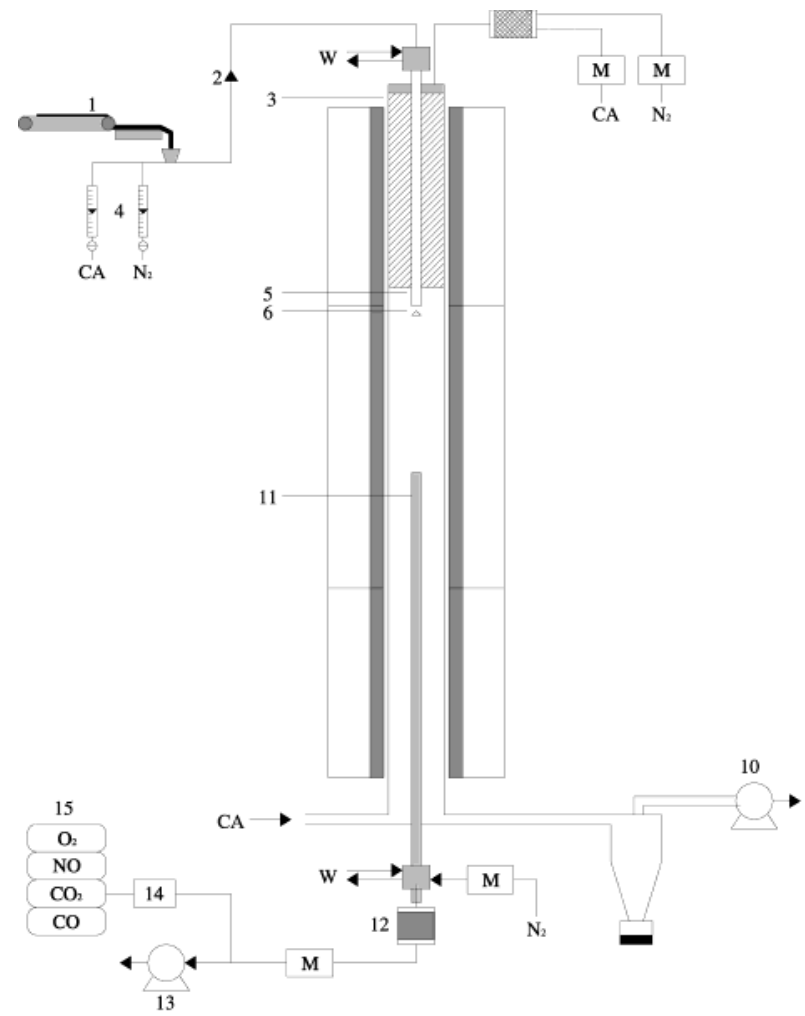

Figure 1. Entrained flow reactor: (1) Conveyor belt/vibrating feeder/ejector; (2) pneumatic transport; (3) electrical preheater; (4) flow meters; (5) water-cool ed feeding probe; (6) dispersion dome; (7) three-zone electrical furnace; (8) $80 \mathrm{~mm}$ i.d. quartz tube reactor; (9) cyclone collector; (10) exhaust fan; (11) water-cooled nitrogen-quenched sampling probe; (12) particle collector (filter); (13) sampling pump; (14) gas conditioner; (15) gas analyzers (infrared/paramagnetic); $M$, mass flow meters and controllers; $\mathrm{N}_{2}$, nitrogen; C.A., compressed air; W, water (probes cooling).

analyzers, and gaseous hydrocarbons were measured with a flame ionization analyzer.

2.2. Samples Characterization. Eight samples were used in this work, six petroleum cokes, a bituminous coal and an activated carbon. The petcokes used in this study were sampled at different industrial sites; no data concerning their origin was available. Table 1 gives the results of the proximate and ultimate analyses. They show very similar compositions in terms of the percentages of $\mathrm{C}$ and $\mathrm{H}$. As expected for heavy petroleum fuels, the natural sulfur contents are high, and range between $4 \%$ and $7.5 \%$. The fuel nitrogen concentrations are similar for all of the petcokes. The proximate analysis indicates low volatile matter and low ash content. The aim of this work was to extract kinetic data for a number of petcokes and to study the influence of the nature of the sample. Then, all the chars were prepared at the same temperature and their reactivity was studied as a function of temperature. The chars were obtained by pyrolyzing the fuel samples in the EFR at
$900{ }^{\circ} \mathrm{C}$. The bituminous coal (Ivan Coal) was used as a reference to a classical fuel, and the activated carbon (AC) was retained as a high BET area carbon for considerations of reactive surface, as discussed further. The analyses of these two fuels are also given in Table 1.

Prior to all analysis and experiments, all the fuels were ground to less than $200 \mu \mathrm{m}$, dried, and the fraction 30-100 $\mu \mathrm{m}$ was selected by pneumatic sieving. Particles of less than $30 \mu \mathrm{m}$ were removed to enable regular feeding of the fuel during EFR experiments.

To obtain a good characterization of the texture of the char samples, the surface areas were measured using two methods:

- nitrogen adsorption at $77 \mathrm{~K}$ with the BET equation,

- mercury porosimetry to quantify the surface area of the mesopores and macropores of the particles. This method was used to measure the surface area of pores larger than $20 \mathrm{~nm}$ $\left(\mathrm{Hg}_{20}\right)$.

The surface $\mathrm{Hg}_{20}$ was here derived from mercury porosimetry tests, using the standard pore model proposed by Satterfield, ${ }^{27}$ in which the pore diameter is calculated from the porosity $\epsilon$, the particle density $\rho_{\mathrm{p}}$, and the pore surface area $\mathrm{S}$ as follows: 26

$$
d_{p}=\frac{4 \epsilon}{\rho_{p} S}
$$

The adsorption of $\mathrm{CO}_{2}$ at $293 \mathrm{~K}$ also allows the determination of a surface area with the help of models such as the Dubinin-Polanyi equation. The problem is that in many experiments, the access of the gaseous reactant to micropores is difficult. As a result, this method was not used in this work. The porosity was obtained by helium pycnometry. Table 1 presents the results of this characterization. The values of the surface areas of the petcokes are very low compared, for instance, to that of the coal, which typically exhibits BET area of several tens or hundreds of $\mathrm{m}^{2} \mathrm{~g}^{-1}$. It should be noted that the petcoke samples exhibit lower surface area than many samples used in previously published studies. ${ }^{5,8,11}$

The concentrations of 7 elements known for their catalytic activity in carbon reactions were analyzed: vanadium, copper, molybdenum, iron, potassium, calcium, and manganese; the results are reported in Table 2 . As in heavy fuel oils, large amounts of vanadium are found. This element is present in quantities as large as $0.26 \%$ of the dry mass in Asland petcoke. The other metals are much less concentrated, apart from iron in St Constant $(0.17 \%)$ and in Lily $(0.061 \%)$.

2.3. Reaction of Chars with NO in the EFR. The reactivity toward NO of chars has been determined from EFR

(24) Radovic, L. R.; Walker, P. L.; J enkins, R. G. Fuel 1983, 62, 849 857.

(25) Aarna, I.; Suuberg, E. M. 27th Symposium (International) on Combustion; The Combustion Institute: Pittsburgh, 1998; pp 29332939.

(26) Commandré, J. M.; Stanmore, B.; Salvador, S. The High Temperature Reaction of Carbon with Nitric Oxide. Combust. Flame 2002, 128, 211-216.

(27) Satterfield, C. N. Mass Transfer in Heterogeneous Catalysis; Krieger Publishing Company: 1981. 
Table 2. Analysis of Five Metals, $\mathrm{K}$, and $\mathrm{Ca}$ in the Petcokes (ppm raw)

\begin{tabular}{lrrrrrrr}
\multicolumn{1}{c}{ sample } & \multicolumn{1}{c}{ V } & Cu & Mo & Fe & K & Mn & \multicolumn{1}{c}{ Ca } \\
\hline Lily & 507 & 9.1 & 7.0 & 615 & 45 & 5.1 & 220 \\
Havre CDP & 819 & & & 6 & & & 180 \\
Asland & 2570 & 1.9 & 1.4 & 93 & 10 & 0.5 & 20 \\
Villauengas & 1390 & 3.8 & 17.3 & 20 & 17 & 2.6 & 100 \\
St Constant & 899 & 6.1 & 26.3 & 1740 & 15 & 17.1 & 150 \\
Niebla & 1830 & 3.1 & 16.6 & 381 & 57 & 6.1 & 2190
\end{tabular}

Table 3. Reduction Yields of NO by the Different Chars during EFR Experiments (in mol \%) ${ }^{\mathrm{a}}$

\begin{tabular}{lrcc}
\hline \multicolumn{1}{c}{ sample } & $800{ }^{\circ} \mathrm{C}$ & $900{ }^{\circ} \mathrm{C}$ & $1000{ }^{\circ} \mathrm{C}$ \\
\hline petcoke Lily & 1.2 & 15.7 & 59.9 \\
petcoke Havre CDP & 6.3 & 15.2 & 58.8 \\
petcoke Asland & 11.1 & 35.0 & 74.7 \\
petcoke Villauengas & 23.0 & 42.4 & 77.4 \\
petcoke St Constant & 3.8 & 18.4 & 63.4 \\
petcoke Niebla & 9.4 & 42.4 & 74.6 \\
coal I van & 57.6 & 84.7 & 96.3 \\
activated carbon & 27.2 & 44.8 & 69.1
\end{tabular}

a The initial NO concentration was 955 ppmv.

experiments. The chars were previously prepared by passing the fuels in $4.16 \% \mathrm{O}_{2}$ in nitrogen through the EFR at $900{ }^{\circ} \mathrm{C}$.

The experiments to characterize the chars reactivities toward NO were carried out at three temperatures-800, 900, and $1000^{\circ} \mathrm{C}$, so that an activation energy can be determined. The particles feed flowrate was $1.5 \mathrm{~g} / \mathrm{min}$. The gas feed flow was a mixture of $955 \mathrm{ppm}$ of $\mathrm{NO}$ in nitrogen, and the flow rate was $10 \mathrm{~L} / \mathrm{min}$ (NTP). Under these experimental conditions, the residence time ranged between 3.25 and $3.6 \mathrm{~s}$, depending on temperature. If we assume a homogeneous dispersion of the particles in the volume of the reactor, the solid concentrations in the tubular reactor are equal to 38, 35, and $32 \mathrm{~g} / \mathrm{m}^{3}$ for experiments at 800,900 , and $1000{ }^{\circ} \mathrm{C}$, respectively.

We report in Table 3 the $\mathrm{NO}$ reduction yield for the different samples as a function of temperature. The decrease of NO concentration between injection and the bottom of the reactor vary between 11 ppmv for Lily petcoke char at $800{ }^{\circ} \mathrm{C}$ and 920 ppmv for the coal char at $1000^{\circ} \mathrm{C}$. It is obvious from these results that the quantity of $\mathrm{NO}$ that can be reduced on petroleum coke, in the presence of an NO concentration similar to that in an industrial furnace, is very large. In agreement with previous studies in this temperature range, the influence of temperature is important. For example, Chan et al. ${ }^{5}$ reported activation energies larger than $200 \mathrm{~kJ} / \mathrm{mol}$ for graphite and char samples.

For all experiments, the concentration of hydrocarbons at the exhaust of the reactor was below 20 ppmv. Small amounts of $\mathrm{CO}$ were detected which could be related mainly to the reaction $2 \mathrm{NO}+2 \mathrm{C} \rightarrow 2 \mathrm{CO}+\mathrm{N}_{2}$. In most cases, the $\mathrm{CO}$ measured was higher than the NO consumed; the excess of CO ranged between 0 and 500 ppmv for all experiments. This excess can be attributed to the desorption of $\mathrm{CO}$ from the oxygen adsorbed on the char.

There have been numerous studies in which the enhancement of the NO reduction rate by $\mathrm{CO}$ was reported. 5,18 This leads to difficulties in the kinetic interpretation of the experimental results since $\mathrm{CO}$ is a product and a reactant. ${ }^{7}$ Two explanations have been presented to explain this behavior:

- the stripping of surface oxides by $\mathrm{CO}$ through the reaction $\mathrm{CO}+\mathrm{C}(\mathrm{O}) \rightarrow \mathrm{CO}_{2}+\mathrm{C}^{*}$. This process can be significant at low temperature when the desorption of surface oxides is slow,

- the catalysis of the reaction $\mathrm{NO}+\mathrm{CO} \rightarrow 0.5 \mathrm{~N}_{2}+\mathrm{CO}_{2}$ by various substances such as the char itself.

It must be noticed that, in other studies, it has been observed that the addition of low concentrations of CO (i.e., below 700 ppmv) does not lead to an increase of the char-NO reaction rate. ${ }^{4}$ The order of the reaction with respect to $\mathrm{CO}$ is also not known. The study of this complex phenomenon was outside the scope of this work, and it was decided to analyze the experimental results in a classical way with a single firstorder kinetic law.

The concentration of $\mathrm{CO}_{2}$ was not significant. This is consistent with previously published studies in which it has been shown that the $\mathrm{CO} / \mathrm{CO}_{2}$ ratio is very high in this temperature range. ${ }^{7}$ The low amount of carbon oxides and hydrocarbons shows also that there is no significant further devolatilization of the chars during the experiments in the EFR.

As expected, the coal char and the activated carbon lead to the highest reaction yield; this can be related to the high surface areas of these two samples. The elemental and proximate analyses of the six petcokes are similar, so that one could expect to observe the influence of the texture of the samples. Among the petroleum coke samples, Havre CDP, which exhibits the highest surface area, does not lead to the highest reduction yield. Therefore, other parameters such as catalytic elements must influence the reactivity.

\section{Discussion}

The rate constants were determined by fitting the experimental results with those from a model. As pointed out by Aarna and Suuberg in their review, ${ }^{7}$ many published results use the mass of $\mathrm{NO}$ divided per mass of char per unit time per unit pressure of NO to define their rate constant. In this work we use a similar definition for the chemical reaction rate constants, but we take into account the surface area of the samples. Therefore, the reaction rate was expressed as follows:

$$
\frac{d m_{\mathrm{NO}}}{\mathrm{dt}}=-\mathrm{k} \mathrm{m}_{\mathrm{C}} \mathrm{S}_{\mathrm{sp}} \eta_{\mathrm{NO}} \mathrm{P}_{\mathrm{NO}}
$$

with

$$
k=A e^{(-E / R T)}
$$

where [NO] is the molar concentration of NO in the gas and $\mathrm{C}_{\mathrm{c}}$ is the concentration of carbonaceous material in the gas. $\eta_{\mathrm{NO}}$ is the effectiveness factor, as cal culated from the Thiele modulus for a reaction order equal to 1. Some authors have observed reaction orders toward NO which range between 0.2 and 0.8 for this reduction reaction. 8,28 Neverthel ess, most studies used a reaction order of 1 , whatever the experimental setup used to obtain the results. 20,22

To fit experimental data, a mass balance was done between the entry and the exhaust of the entrained flow reactor. The main assumptions of this model are the following:

- the zone close to the axis is a plug flow reactor,

- the dispersion of the particles in the gas is homogeneous,

- the particles velocity is equal to the gas velocity.

The details of the cal culations are given elsewhere. ${ }^{26}$ An iterative computation was used to obtain the effectiveness factor $\eta_{\mathrm{NO}}$ and the Arrhenius parameters for each sample.

The plots in Figure 2 and Figure 3 allow the comparison between the reactivities of the different petcoke chars and that of the coal char. Shimizu et al. were able to find a correlati on between $\mathrm{CO}_{2}$ surface area and NO-

(28) Schuler, J .; Baumann H.; Klein, J . Kinetics of NO reduction by coal char. Conf. (Int.) Coal Sci. 1987, 857-860. 


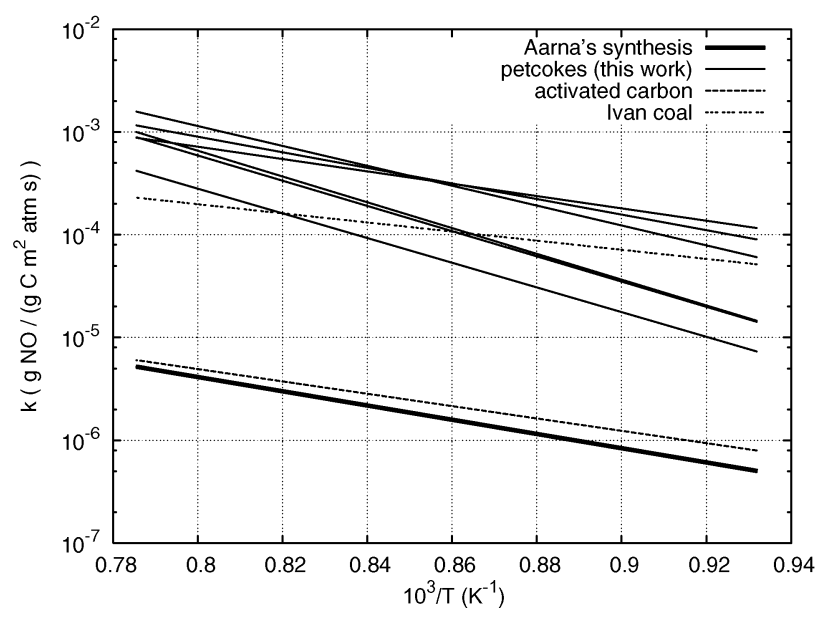

Figure 2. Arrhenius representation for the reaction rate of carbon toward NO, specified on BET area.

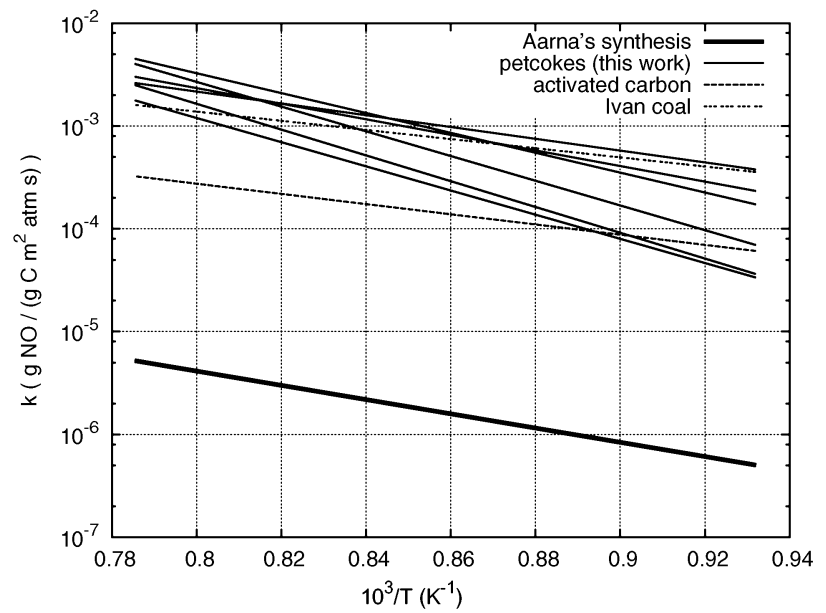

Figure 3. Arrhenius representation for the reaction rate of carbon toward $\mathrm{NO}$, specified on $\mathrm{Hg}_{20}$ area.

char reactivity, ${ }^{11}$ but this was not possible in some others studies. ${ }^{8}$ Aarna and Suuberg ${ }^{7}$ have proposed a synthesis of the reaction rates, specified on BET areas, derived by a number of authors. Their correlation was converted to the same units as the ones used in this work, and plotted in Figures 2 and 3 . The spread in the reaction rates is much more important in Figure 2 , on BET area base, than in Figure 3, which was plotted on $\mathrm{Hg}_{20}$ base.

Radovic et al. ${ }^{24}$ expressed as early as 1983 that BET area is an inadequate basis for the expression of reactivity. Aarna and Suuberg ${ }^{25}$ showed that micropores hardly participate in the reaction between oxygen and carbon. In a recent work by Salvador et al., ${ }^{3}$ it was shown that the scatter in the reactivities of carbons of various forms was much smaller when the surface of the pores larger than $20 \mathrm{~nm}\left(\mathrm{Hg}_{20}\right)$ was used to express the reactive surface, instead of the total pore surface. This tends to confirm that micropores smaller than 20 $\mathrm{nm}$ do not participate in the reaction. A study on the reactivity of carbons issuing from different origins with $\mathrm{NO}$ lead Commandre et al. ${ }^{26}$ to the same conclusion.

It appears to be the case that excluding the surface area of the small pores (i.e., with diameters lower than $20 \mathrm{~nm}$ ) from the reactive surface reconciles the data from various forms of carbon; and thus $\mathrm{Hg}_{20}$ surface area is likely to be a better indicator of the real reactive
Table 4. Activation Energies and Effectiveness Factor $\eta_{\text {NO }}$ for NO Reduction (computed with $\mathbf{H g}_{20}$ surface area)

\begin{tabular}{lcc}
\hline \multicolumn{1}{c}{ sample } & $\begin{array}{c}\text { activation energy } \\
(\mathrm{kJ} / \mathrm{mol})\end{array}$ & $\begin{array}{c}\text { effectiveness } \\
\text { factor }(-)\end{array}$ \\
\hline petcoke Lily & 240 & $0.928-0.999$ \\
petcoke Havre CDP & 230 & $0.936-0.999$ \\
petcoke Asland & 185 & $0.883-0.994$ \\
petcoke Villauengas & 115 & $0.940-0.990$ \\
petcoke St Constant & 235 & $0.902-0.998$ \\
petcoke Niebla & 145 & $0.944-0.995$ \\
coal I van & 85 & $0.879-0.968$ \\
activated carbon & 115 & $0.992-0.998$
\end{tabular}

surface than BET. We have al ready reported this result for carbon oxidation in a previous work. ${ }^{3}$ Petcokes again exhibit very high reactivities as compared with results from the literature. ${ }^{7}$

Most authors have observed that the activation energy increases in value at temperatures between 800 and $1000 \mathrm{~K}$. Although there are large variations in the measured activation energies, the values generally measured change from $75 \mathrm{~kJ} / \mathrm{mol}$ bel ow $950 \mathrm{~K}$ to 180 $\mathrm{kJ} / \mathrm{mol}$ above this temperature.5,20,29 The low activation energy observed at low temperature has been related to the limitation by the desorption of reaction products; a limitation which disappears as the temperature increases. The rate of the high temperature reaction is therefore controlled by the dissociative adsorption of NO on the carbon surface. As shown in Table 4, we observed large variations of the activation energies of the different samples tested in this study, as the values obtained with the six petcokes range from 115 to $240 \mathrm{~kJ} / \mathrm{mol}$. These values are in good agreement with previously published data. It must be noticed that the three samples which lead to activations energies close to 235 $\mathrm{kJ} / \mathrm{mol}$ are the ones which have a low vanadium content. This value is in the highest range of activation energies found in the literature, ${ }^{5,15,29}$ and may be related to the non-catalyzed reaction of $\mathrm{NO}$ with carbon.

The catalytic effect of metals on the reaction of $C$ with NO can be estimated from Figures 4 and 5 where the metal concentration was plotted versus the reaction rate at $1200 \mathrm{~K}$, using $\mathrm{Hg}_{20}$ as the area base. Figure 5 shows that a clear correlation appears between the vanadium content of the petcokes and reactivity toward NO. The correlation factor for the linear least-squares estimation is $r^{2}=0.72$. This shows that vanadium can have a catalytic effect even in the case of a rapid reaction. The ratio between the reaction rate of the more reactive petcoke and that of the less reactive one is 3.5. The two other elements which are presented in this figure are iron and calcium; it can be observed that there is no clear correlation between reaction rate and the concentrations of these two elements. As pointed out in the Introduction, Ca has often been presented as an active catalyst for reduction reactions. . $^{97,19}$ It must be noticed that the concentration of $\mathrm{Ca}$ in petcoke is lower than that of the char samples used in most studies. The concentration of iron in petcoke is high and an influence of this metal on the NO-har reaction rate could be expected. ${ }^{30}$ Nevertheless, this catalytic activity of iron

(29) Furusawa, T.; Tsunoda, M.; Tsujimura, M.; Adschiri, T. Nitric oxide reduction by char and carbon monoxide. Fuel 1985, 64 (9), 1306-1309.

(30) Allen, D.; Hayhurst, A. N. FBC Technology and the Environmental Challenge; Adam Hilger: Bristol, U.K., 1991. 


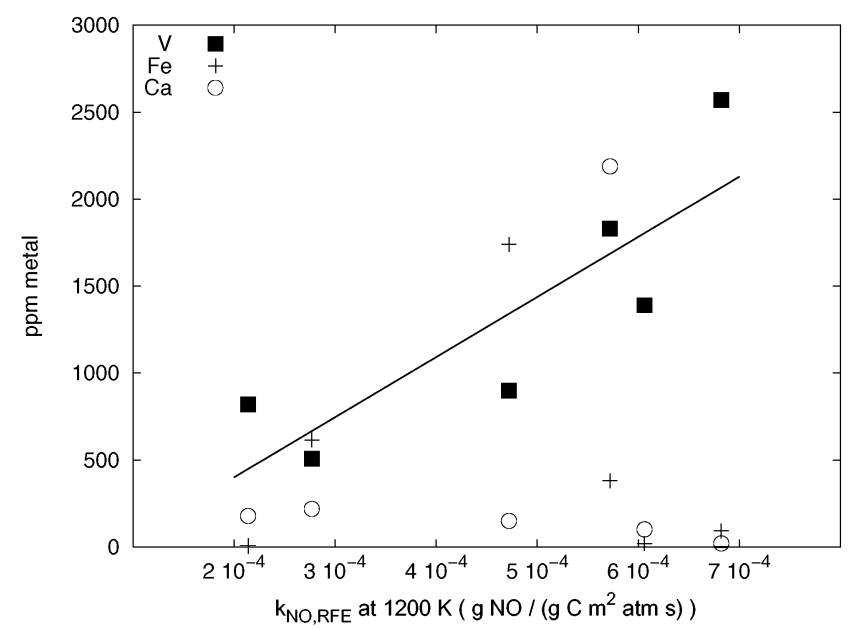

Figure 4. $\mathrm{V}, \mathrm{Fe}$, and $\mathrm{Ca}$ content of the petcokes versus their reaction rate toward NO at $1200 \mathrm{~K}$. The line is a linear correlation for vanadium.

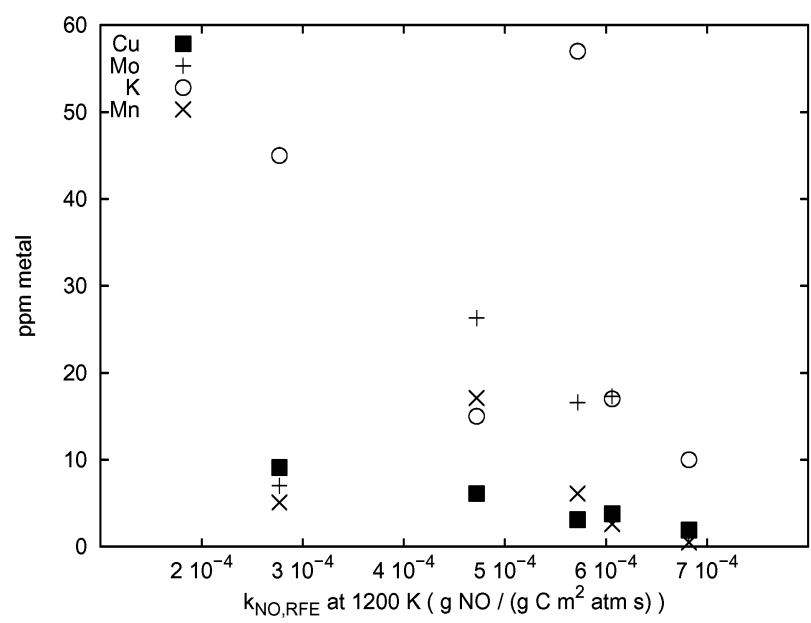

Figure 5. Trace metals content of the petcokes versus their reaction rate toward $\mathrm{NO}$ at $1200 \mathrm{~K}$.

was not observed in some other studies, ${ }^{9}$ and IllianGomez et al. ${ }^{13}$ observed a high activity of Fe only at low temperature (i.e., below $700 \mathrm{~K}$ ).

Figure 5 presents the four metals which are present in low concentration in petroleum cokes. Although potassium has often been found as an active el ement whatever the temperature, ${ }^{15}$ it is obvious that its low concentration leads to a negligible influence on char reactivity compared to that of vanadium. The same explanation can be applied for copper, molybdenum, and manganese.
The calculation of the particlerelated effectiveness factor (foll lowing the model of Commandre et al ${ }^{26}$ ) leads to values between 0.7 and 1 if BET surface area is used. As it is presented in Table 4, if $\mathrm{Hg}_{20}$ surface area is used, $\eta_{\mathrm{NO}}$ is above 0.88 for all the samples whatever the experimental temperature. This shows that NO mass transfer in the porous structure of the chars does not control the reaction yield. This explains why the catalytic effect of vanadium on the reaction is clearly evident here. This was not the case for the reaction of $C$ with $\mathrm{O}_{2}$ from air during our TG experiments, where oxygen transfer was apparently limiting the combustion vel ocity. $^{3}$

\section{Conclusion}

A study of the reaction of $\mathrm{NO}$ on petroleum cokes has been carried out in an entrained flow reactor. It was observed that petcokes are very reactive forms of carbon in the heterogeneous reaction of carbon with NO, resulting in NO concentration depletions of hundreds of ppmv after a residence time of less than $1.5 \mathrm{~s}$ at temperatures in the range $800-1000{ }^{\circ} \mathrm{C}$.

F or the heterogeneous reaction considered, we have shown that excluding the surface of the pores smaller than several tens of nanometers from the total pore surface lead to more uniform values for the reaction rates of chars from different origins. This tends to confirm the assumption that small pores do not participate in these heterogeneous reactions. We think that the surface area of the pores larger than $20 \mathrm{~nm}$ which is cal culated from mercury porosimetry measurements is a better estimate of the reactive surface than the total pore area determined by classical BET tests or by $\mathrm{CO}_{2}$ adsorption experiments.

A ratio of 3.5 is indicated between the reaction rates at $1200 \mathrm{~K}$ of the more reactive and the less reactive petcoke chars. Seven elements (vanadium, copper, molybdenum, iron, potassium, calcium, and manganese) which are known as catalysts for this sort of reaction were analyzed to explain the different reactivities of petcokes. Although petroleum cokes are low-ash-content fuels, the analysis of these seven elements indicated vanadium contents as high as $0.26 \%$. Among these elements, vanadium appears to be responsible for the high variation of reactivities which are observed for the petcoke chars, and a clear correlation could be found between the vanadium content of the sample and its reactivity toward NO.

EF0300489 